\title{
Enhances production of coffee (Coffea robusta): The role of pollinator, forages potency, and honey production from Tetragonula sp. (Meliponinae) in Central Lombok, Indonesia
}

\author{
BAMBANG SUPENO ${ }^{1, \boldsymbol{v}}$, ERWAN $^{2}$, AGUSSALIM $^{3}$ \\ ${ }^{1}$ Faculty of Agriculture, Universitas Mataram. Jl. Majapahit No. 62, Mataram 83125, West Nusa Tenggara, Indonesia. Tel. +62-370-621435, Fax. +62- \\ 370-640189. •email: bsupeno59@unram.ac.id \\ ${ }^{2}$ Faculty of Animal Science, Universitas Mataram. Jl. Majapahit No. 62, Mataram 83125, West Nusa Tenggara, Indonesia \\ ${ }^{3}$ Faculty of Animal Science, Universitas Gadjah Mada. Jl. Fauna 3, Bulaksumur, Sleman 55281, Yogyakarta, Indonesia
}

Manuscript received: 14 September 2021. Revision accepted: 30 September 2021.

\begin{abstract}
Supeno B, Erwan, Agussalim. 2021. Enhances production of coffee (Coffea robusta): The role of pollinator, forages potency, and honey production from Tetragonula sp. (Meliponinae) in Central Lombok, Indonesia. Biodiversitas 22: 4687-4693. The bees role as an agent of pollinators to improve the productivity of plants. This study was purposed to enhance coffee production (Coffea robusta) by roles of stingless bee Tetragonula sp. as pollinator agent, forages potency, and honey production. This study has been conducted in a coffee plantation in Lantan, Central Lombok, Indonesia. Several parameters were measured such as the number of bunches and flowers, production of nectar and pollen, nectar sucrose content, production of coffee, and production of honey. The results showed that the different observation time influenced the number of bunches, flowers, production of nectar and pollen, nectar sucrose content $(\mathrm{P}<0.01)$. The number of bunches ranged from 58.20 to 144.87 bunches/tree, the number of flowers 36.33 to 58.73 flowers/bunches, and 2,362.53 to 8.250 .63 flowers/tree. Furthermore, the nectar production 9.16 to $34.01 \mathrm{~g} /$ tree, pollen production 1.72 to $5.99 \mathrm{~g} /$ tree, nectar sucrose content 20.6 to $35.0 \%$. Estimation of coffee production before pollinated by Tetragonula sp. was $1,230.8 \mathrm{~kg} / \mathrm{ha}$, but after pollination by Tetragonula was increased it became $3,605.7 \mathrm{~kg} / \mathrm{ha}(49.1 \%)$. Fruit production before pollinated by Tetragonula sp. was $2,127.2$ fruit/tree, but after pollination by Tetragonula sp. increased to 8,309.2 fruit/tree (59.2\%). Production of honey from Tetragonula sp. was $3.74 \mathrm{~g} / \mathrm{hive} / 5$ months and in Apis cerana was $301.35 \mathrm{~g} / \mathrm{hive} / 5$ months. It can be concluded that the Tetragonula sp. as an agent of pollinators can enhance the production of coffee and increase the biodiversity of coffee.
\end{abstract}

Keywords: Biodiversity, coffee flowers, nectar, pollination, pollen

\section{INTRODUCTION}

Estates has an area 23.63 thousand hectares and in 2018 became 19.92 thousand hectares and in 2019 it decreased to 14.5 thousand hectares. Furthermore, Private Estates also decreased where in 2017 it has an area 23.19 thousand hectares and decreased in 2018 became 22.25 thousand hectares, and in 2019 decreased became 9.71 thousand hectares. The decrease of coffee plantation area is caused by the land conversion in several provinces. However, in Smallholders Estates it increased in 20171.192 million hectares, then in 2018 became 1.210 million hectares and in 2019 increased 1.215 million hectares. The decrease of coffee plantation area is impacted by the decrease in coffee production. The production of coffee in Indonesia from year of 2017 to 2019 is fluctuating where the production of coffee in 2017 is 30.29 thousand ton and decreased to 28.14 thousand in 2018 (decreased 7.1\%) and in 2019 decreased to 10.01 thousand ton (BPS-Statistics Indonesia 2019). In West Nusa Tenggara Province, Indonesia showed that smallholders coffee area in 2016 is 12,256 ha with coffee production is 4,641 tons (BPS-Statistics Indonesia 2017) and in 2017 is decreased became 11,978 ha with coffee production is 4,865 tons (BPS-Statistics Indonesia 2018) and in 2018 is decreased became 11,942 ha with coffee production 5.037 tons (BPS-Statistics Indonesia 2019).

To increase the coffee production requires the role of insects to pollinate their flowers and one of the insects as the best pollinators is honeybees or stingless bees. Coffee flowers produce nectar and pollen for honeybees or stingless bees food. Nectar and pollen are used by honeybees or stingless bees to produce honey and bee bread which are required for their growth and development in the colonies (Abrol 2011; Agussalim et al. 2018). When coffee flower blooming is usually found the honeybees or stingless bees visit the flowers to collect nectar and pollen. Stingless bee species that can be found in Lombok include Tetragonula species (Meliponinae) that can produce honey, bee bread, and propolis (Agus et al. 2019; Agussalim et al. 2019, 2020, 2021; Erwan et al. 2020, 2021). Furthermore, when the bees collect nectar and pollen indirectly, they serve as an agent of pollinators, which increases the productivity of coffee. Coffee flowers include in hermaphrodite where they are can perform the self-pollination, but assumed is predominant pollinated by wind, however the cross pollination by the bees can significantly increase the production of coffee (Coffea canephora) (Klein et al. 2003; Quezada-Euan 2018; Roubik 2002). In Mexico, the main visitor in coffee flowers is the honeybee Apis mellifera for about $84 \%$ of the 
total of visitors. Furthermore, stingless bee Trigona corvina also reported their visit for about $6 \%$ of total of visitors (Vergara and Badano 2009).

Klein et al. (2003) reported that the insects that serve as pollinators are mostly pollinated by the bees, ranging from 2,038 to 2,269 bees that visit coffee flowers. Several studies showed that honeybees or stingless bee can improve the productivity of several plants such as number of fruits, weight, length, and other parameters from various countries (Atmowidi et al. 2008; Azmi et al. 2016; Bezabih and Gebretsadikan, 2014; Calderone 2012; Putra and Kinasih 2014; Kishan Tej et al. 2017; Layek et al. 2021; Putra et al. 2014; Rogers et al. 2014; Veddeler et al. 2008). However, the studied the roles of stingless bee Tetragonula sp. as an agent of pollinators in coffee (Coffea robusta) in Central Lombok, Indonesia has not been studied. Therefore, the objectives of this study are to enhance coffee production (Coffea robusta) by roles of stingless bee Tetragonula sp. as an agent of pollinator, forages potency from coffee flowers, and evaluates the honey production from Tetragonula sp. in Central Lombok, West Nusa Tenggara Province, Indonesia.

\section{MATERIALS AND METHODS}

\section{Study area}

This study has been conducted in the coffee plantation managed by communities in forest area (smallholders) in Lantan (8'29'39'S 116 20'33'E) located at 507 above sea level, North Batukliang Sub-district, Central Lombok District, West Nusa Tenggara Province, Indonesia was shown in Figure 1.

\section{Procedures}

One hundred coffee flowers were wrapped for about 9 months using gauze (size $10 \times 10 \mathrm{~cm}$ ) (Figure 2) that have been counted to determine their ability to self-pollinate. Afterward, the coffee fruit amount was counted for each wrap. Furthermore, the flowers percentage that became fruit from the treatment without stingless bee pollinated and pollinated by stingless bee was calculated by the equation: Flowers percentage $=$ (flowers amount per bunch - coffee fruit) x $100 \%$

The flowering characteristic of coffee was obtained by observing from April to November. The nectar production from coffee flowers and the capacity of coffee plantation per hectare for stingless bee meliponiculture. Thirty coffee trees were chosen randomly, and each tree was counted production per bunch, flowers amount per bunch. Afterwards, the flowers were taken 4 bunches and were counted flowers per bunches randomly. The number of blooming flower bunches, blooming flowers per bunches, and flowers per coffee tree were counted directly from the coffee plant. The colonies of stingless bee Tetragonula sp. was used as an agent of pollinator for coffee plants were 20 colonies per hectare of coffee plantation.

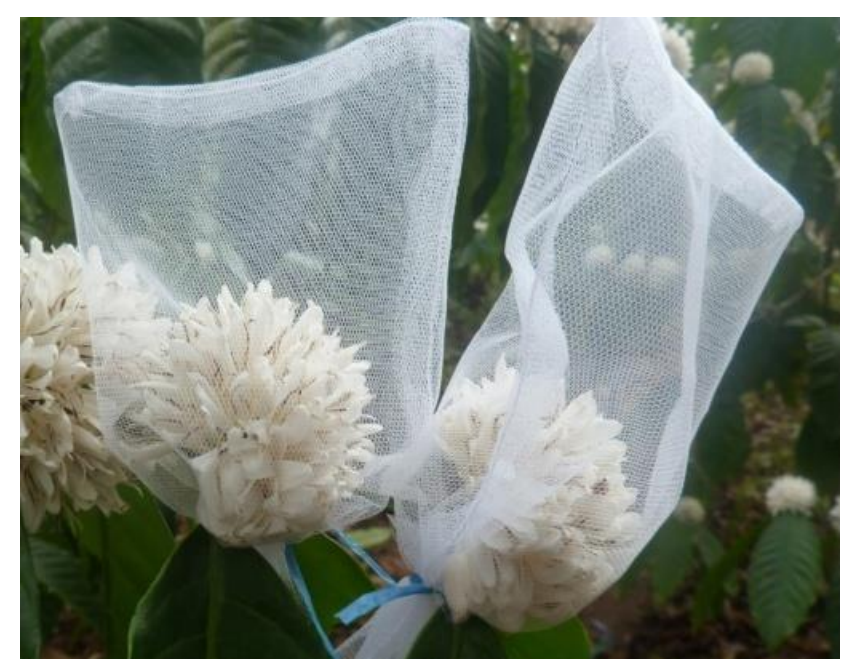

Figure 2. Coffee flowers were covered by gauze used in this study

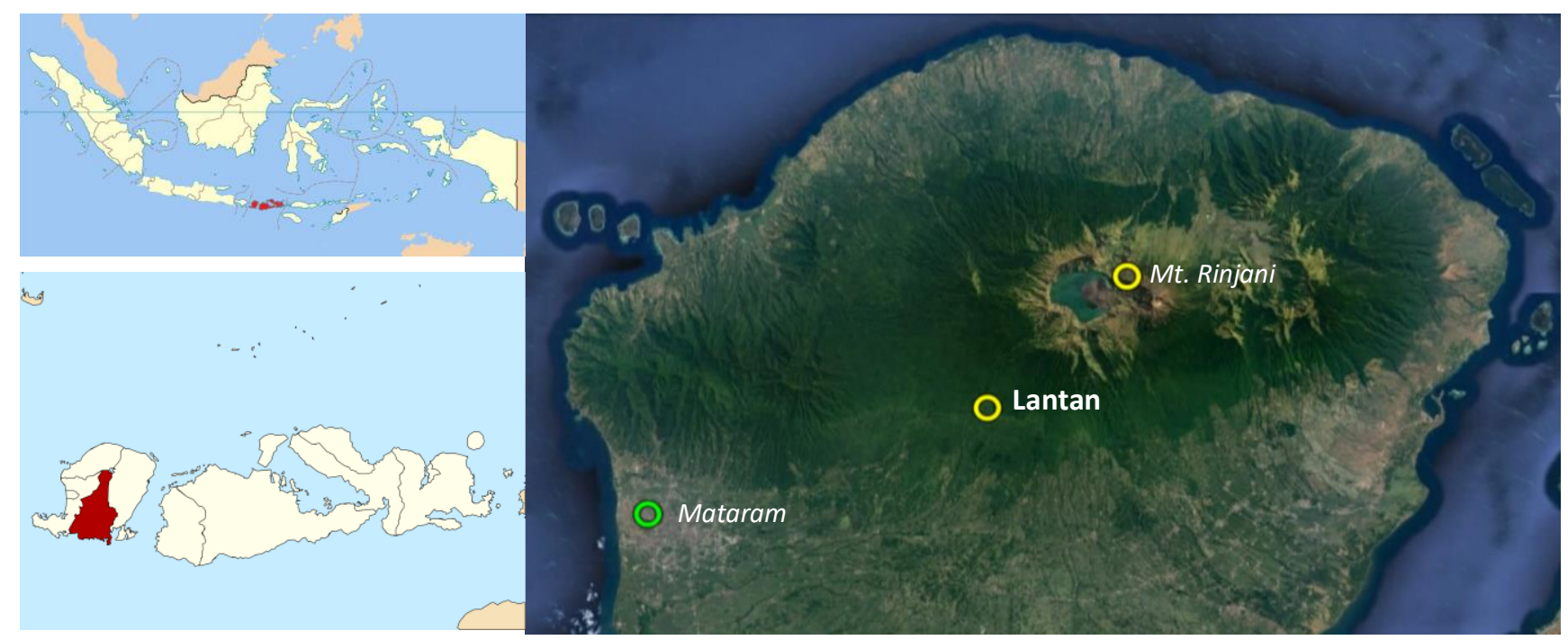

Figure 1. The location of coffee plantation in Lantan, Central Lombok District, West Nusa Tenggara Province, Indonesia 


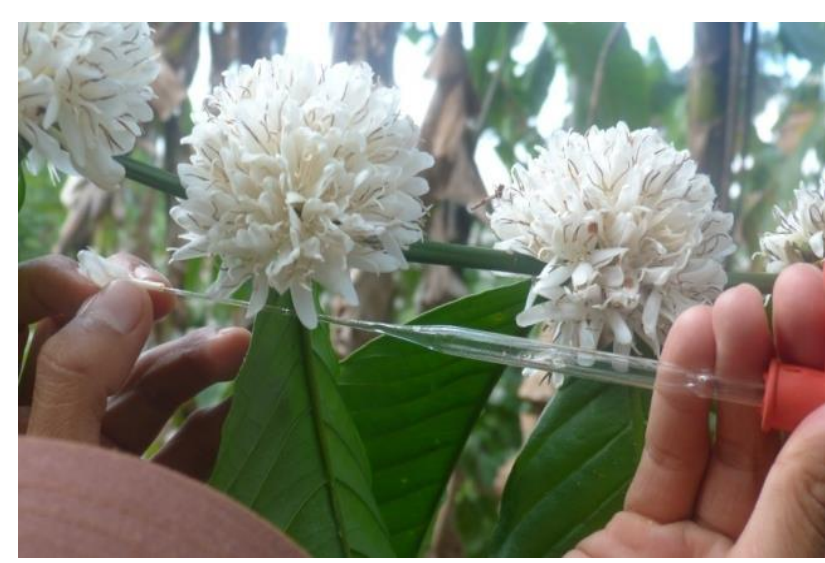

A

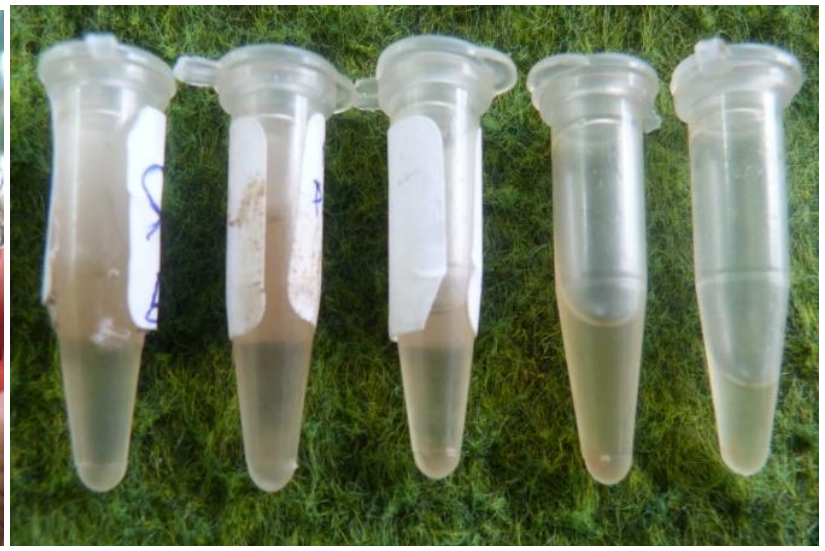

B

Figure 3. Coffee flowers when collected a nectar (A) and nectar has been collected put in Eppendorf tubes (B)

Nectar collecting and their sucrose content

Coffee flowers were covered by gauze (Figure 2) before collecting their nectar from 18 coffee bunches and their bunches were at least 50 flowers. Every 2 bunches that blooming flowers were collected their nectar using a glass pipette has been modified (Figure 3.A) in the morning (06.00 to 09.00$)$, afternoon (11.00 to 13.00), and evening (16.00 to 18.00$)$ in one day every period of flowers blooming. Afterwards, the nectar was put into the Eppendorf tube (Figure 3.B) and then analyzed using the Luff Schoorl method as described by AOAC (2005). All analyses were performed in triplicates and each in duplo.

\section{Production of nectar and pollen of coffee flowers}

The production of nectar from coffee flowers was measured from 1,220 flowers and the average of each flower was counted. Production of nectar from one flower was measured from one flower sample and sucked by a glass pipette has been modified (Figure 3.A) and weighed by digital scale. For production of nectar per coffee tree was counted from the number of flowers per coffee tree multiplied by production of nectar per flower. The production of nectar per hectare of coffee plantation was counted by the production of nectar per coffee tree multiplied by the number of coffee trees per hectare (coffee trees per hectare were 1,322 trees). The pollen production from coffee flowers were measured from 1,062 flowers and then were counted as the average of each flower. The production of nectar and pollen each month was counted from the number of flowers per tree multiplied by production of nectar and pollen from each flower and measured from July to October. The total production of nectar and pollen were counted as the production total from July to October. The total production of nectar from coffee flowers was counted from the sum of nectar from 4 month from July to October period and production per hectare of plantation also was counted.

\section{Estimation of coffee production}

Estimation of coffee production was counted from the production of coffee per tree multiplied by the number of coffee trees per hectare (coffee trees per hectare of plantation were 1,322 trees) and was counted during May to October each for the flowers covered by gauze (without stingless bee pollinate) and pollinated by stingless bee Tetragonula sp. Production of coffee before pollination by stingless bees was obtained from the data previously collected by farmers.

\section{Data analysis}

The data of number of bunches, flowers, production of nectar and pollen, and nectar sucrose content were analyzed using one-way analysis and followed by the Tukey test using SPSS (Windows version of SPSS, release 23). The data of total bunches per coffee, flowers per bunches, flowers per coffee and the total production of nectar and pollen per hectares, and production of honey were analyzed by descriptive analysis using Microsoft excel (Steel et al. 1997).

\section{RESULTS AND DISCUSSION}

\section{Number of bunches and flowers}

The results showed that the number of bunches per coffee tree were differed among the observation months. The number of bunches per tree from the highest was 144.87 bunches/tree in September, followed by October was 119.87 bunches/tree, August was 83.20 bunches/tree and the lowest in July was 58.20 bunches/tree $(\mathrm{P}<0.01)$ (Table 1). This condition, in line with the flower number per coffee tree where in September as the peak of flowering in coffee was 8,250.63 flowers/ tree, followed by October was 5,534.33 flowers/tree, August was 3,025.57 flowers/tree, and decreased in July was 2,362.53 flowers/tree. In addition, the coffee tree in Lantan, Central Lombok when we studied showed that the flowering was delayed and started in July, though usually flowering started in May to July periods. Furthermore, the number of flowers per bunch was higher in September was 58.73 flowers/bunch, followed by October was 45.93 flowers/bunch, and decreased in July and August were 39.60 flowers/bunch and 36.33 flowers/bunch, respectively (Table 1). 
The difference in the number of bunches and flowers from the coffee tree each month may be affected by the difference in the ability in each plant to grow and absorb the soil nutrients that are used to produce flowers in each bunch. Based on the number of bunches and flowers per coffee tree indicates potential as an area for beekeeping of honeybees or meliponiculture of stingless bees. The number of coffee flowers per plant in our study was different from previously studied by Bareke et al. (2021) that the number of flowers per plant for Coffea arabica $\mathrm{L}$. is ranged from 485 to 2330 flowers/plant.

Pearson correlation showed that the number of blooming flower bunches per coffee has a positive correlation with blooming flowers per bunches $(r=0.256$, $\mathrm{p}<0.001)$ and number of flowers per coffee $(r=0.772$, $\mathrm{p}<0.001$ ). In addition, the blooming flowers per bunches has a positive correlation with the number of flowers per coffee $(r=0.778, p<0.001)$ (Table 3$)$. It indicates that the higher number of blooming flowers, blooming flowers, and flowers of coffee trees have an impact on increased the production of nectar and pollen from coffee trees. Therefore, it can support the availability of nectar and pollen for honeybees or stingless bees to support the increase of biodiversity especially coffee trees.

The total number of bunches per coffee tree was 421.63 bunches/tree/4 months and the number of flowers per bunches was 180.60 flowers/bunches/4 months. Furthermore, the total number of flowers per coffee tree was 19,173 flowers/tree/4 months, while per hectare of plantation was 25,352,815 flowers/ha (Table 2). It indicates that the coffee plantation has potential to support the nectar and pollen for honeybees or stingless bees. Thus, in the future a comprehensive study is needed about the production of honey and bee bread from honeybees or stingless bees and the quality of honey or bee bread based on their chemical composition.

\section{Production of nectar and pollen}

The results showed that the production of nectar from one coffee flower was $4.12 \mathrm{mg} /$ flower, while the pollen production was $0.73 \mathrm{mg} /$ flower. It indicates that the coffee flowers have the potential as the source of nectar and pollen for honeybees or stingless bee forages. The results showed that the production of nectar and pollen from coffee flowers each month was different. The production of nectar from coffee flowers was higher in September period was $34.01 \mathrm{~g} /$ tree, followed by October was $22.81 \mathrm{~g} /$ tree, August was $12.47 \mathrm{~g} /$ tree, and decreased in July period was $9.16 \mathrm{~g} /$ tree (Table 1). Coffee flowers was produced the nectar for 3 days and depend on climate or season, when the rain season flowers when flowers are started blooming so the flowers just can produce nectar for 2 days.

Table 2. The total number of bunches, flowers and total production of nectar and pollen from coffee flowers

\begin{tabular}{lcc} 
Parameters & $\begin{array}{c}\text { Total } \\
\text { (4 months) }\end{array}$ & $\begin{array}{c}\text { Per } \\
\text { hectare } \\
\text { (ha) }\end{array}$ \\
\hline Total number of bunches per tree & 421.63 & - \\
Total number of flowers per bunches & 180.60 & - \\
Total number of flowers per tree & 19,173 & $25,352,815$ \\
Total production of coffee nectar $(\mathrm{g})$ & 78.45 & $103,739.44$ \\
Total production of coffee pollen $(\mathrm{g})$ & 13.92 & $18,405.86$ \\
\hline
\end{tabular}

Note: Production of nectar $(\mathrm{n}=1,220$ flowers) and pollen $(\mathrm{n}=$ 1,062 flowers) of coffee flowers and coffee trees were 1,322 trees/ha.

Table 1. The mean of bunches number, number flowers and production of nectar and pollen of coffee flowers during July to October periods

\begin{tabular}{lllll}
\hline \multirow{2}{*}{ Parameters } & \multicolumn{3}{c}{ Observation months } \\
\cline { 2 - 5 } & July & August & September & October \\
\hline Number bunches per tree & $58.20 \pm 4.27^{\mathrm{d}}$ & $83.20 \pm 3.46^{\mathrm{c}}$ & $144.87 \pm 6.58^{\mathrm{a}}$ & $119.87 \pm 7.39^{\mathrm{b}}$ \\
Number flowers per bunches & $39.60 \pm 2.15^{\mathrm{b}}$ & $36.33 \pm 2.01^{\mathrm{b}}$ & $58.73 \pm 3.51^{\mathrm{a}}$ & $45.93 \pm 3.75^{\mathrm{b}}$ \\
Number flowers per tree & $2,362.53 \pm 262.19^{\mathrm{d}}$ & $3,025.57 \pm 213.67^{\mathrm{c}}$ & $8,250.63 \pm 534.78^{\mathrm{a}}$ & $5,534.33 \pm 578.69^{\mathrm{b}}$ \\
Production of nectar (g/tree) & $9.16 \pm 1.08^{\mathrm{c}}$ & $12.47 \pm 0.88^{\mathrm{c}}$ & $34.01 \pm 2.20^{\mathrm{a}}$ & $22.81 \pm 2.39^{\mathrm{b}}$ \\
Production of pollen (g/tree) & $1.72 \pm 0.19^{\mathrm{c}}$ & $2.20 \pm 0.16^{\mathrm{c}}$ & $5.99 \pm 0.39^{\mathrm{a}}$ & $4.02 \pm 0.42^{\mathrm{b}}$ \\
\hline
\end{tabular}

Note: ${ }^{\text {a,b,c,d }}$ Different superscripts within rows indicate differences at $\mathrm{P}<0.01$; Data was presented in mean \pm standard error

Table 3. Pearson correlation numbers of blooming flowers bunches per coffee, blooming flowers per bunches, flowers per coffee, production of nectar and pollen from coffee flowers

\begin{tabular}{|c|c|c|c|c|c|c|}
\hline & & 1 & 2 & 3 & 4 & 5 \\
\hline 1 & Production of nectar & 1 & & & & \\
\hline 2 & Production of pollen & $1.000 * *$ & 1 & & & \\
\hline 3 & Blooming flowers bunches & $0.772 * *$ & $0.772 * *$ & 1 & & \\
\hline 4 & Blooming flowers & $0.778 * *$ & $0.778 * *$ & $0.256 * *$ & 1 & \\
\hline 5 & Flowers & $1.000 * *$ & $1.000 * *$ & $0.772 * *$ & $0.778 * *$ & 1 \\
\hline
\end{tabular}

Note: **Indicates significant at $\mathrm{P}<0.01(2$-tailed) 
However, in our study it was differ from reported by Bareke et al. (2021) that the Coffea arabica L. flowers produced nectar for 5 days where the production peak of nectar in the second day and decreased in the third day until the fifth day. The production of pollen from coffee flowers was higher in the September period was 5.99 $\mathrm{g} / \mathrm{month}$, followed by October was $4.02 \mathrm{~g} /$ coffee, in August was $2.20 \mathrm{~g} /$ coffee, and decreased in July period was 1.72 $\mathrm{g} /$ coffee (Table 1). The total of nectar production for 4 months from one coffee tree was $78.45 \mathrm{~g} /$ tree, while the production per hectare of plantation was $103,739.44 \mathrm{~g} / \mathrm{ha}$ (Table 2). Based on production of nectar per plant and per hectare plantation indicates that the coffee flowers are the potential nectar source for honeybees or stingless bees. The production of nectar from coffee flowers were positively correlated with the number of blooming flowers bunches $(r$ $=0.772, \mathrm{P}<0.01)$, blooming flowers $(\mathrm{r}=0.778, \mathrm{P}<0.01)$, and number of flowers $(\mathrm{r}=1.000, \mathrm{P}<0.01)$ (Table 3$)$.

Production of nectar from one of the coffee flowers in our study was differ from that reported by Manila-fajardo and Cervancia (2020) for Coffea liberica var. liberica is ranged from 4.22 to $14.43 \mu \mathrm{L}$. Furthermore, production of nectar per coffee Coffea arabica L. flowers in 07.00 to 18.00 hours is ranged from 2.5 to $6.6 \mu \mathrm{L}$ (Bareke et al. 2021). The production of nectar from coffee flowers is affected by coffee cultivars, plant age, season or climate (include temperature, humidity), and availability of soil nutrients and their ability to absorb of soil nutrients.

The production of pollen from coffee flowers was higher in the September period was $5.99 \mathrm{~g} /$ coffee, followed by October was $4.02 \mathrm{~g} /$ coffee, in August was $2.20 \mathrm{~g} /$ coffee, and decreased in July period was $1.72 \mathrm{~g} /$ coffee (Table 1). Furthermore, the production of pollen for one coffee tree was $13.92 \mathrm{~g} / 4$ months and the total production of pollen from one hectare plantation was 18,405.86 g/ha. It indicates that the availability of coffee pollen can support beekeeping or meliponiculture and to increase the coffee production by cross pollination from pollen from each coffee plant. The production of pollen from coffee flowers were positively correlated with the number of blooming flowers bunches $(\mathrm{r}=0.772, \mathrm{P}<0.01)$, blooming flowers $(\mathrm{r}=$ $0.778, \mathrm{P}<0.01)$, and number of flowers $(\mathrm{r}=1.000, \mathrm{P}<0.01)$ (Table 3). It indicates that the coffee flowers have the potential to produce pollen as the honeybees or stingless bee's food.

\section{Nectar sucrose content}

The results showed that the nectar sucrose content from coffee flowers were differ during the time to collecting in the morning, afternoon, and evening for first, second, and third days collecting, respectively. On the first day, the nectar sucrose content in the morning (23.3\%) and afternoon $(23.3 \%)$ were similar and higher than nectar sucrose content in evening was $23.2 \% \quad(\mathrm{P}<0.01)$. Furthermore, in the morning $(24.4 \%)$ and afternoon (24.4) were similar and lower than nectar sucrose content in evening was $27.1 \%$ for second day and the third day was higher in afternoon was $35.0 \%$, followed by evening was
$29.0 \%$, and the lowest in morning was $20.6 \% \quad(\mathrm{P}<0.01)$ (Table 4).

The different days to collecting nectar from coffee flowers have an impact on the difference of nectar sucrose content. The nectar sucrose content of coffee flowers when collected in the morning was higher on the second day was $24.4 \%$, followed by the first day was $23.3 \%$, and the lowest on the third day was $20.6 \%(\mathrm{P}<0.01)$. In the afternoon the nectar sucrose content was higher on the third day was $35.0 \%$, followed by the second day was $24.4 \%$, and the lowest on the first day was $23.3 \%(\mathrm{P}<0.01)$. Furthermore, in the evening the higher nectar sucrose content on the third day was $29.0 \%$, followed by the second day was $27.1 \%$, and the lowest on the first day was $23.2 \%(\mathrm{P}<0.01)$ (Table 4 ). The nectar sucrose content in our study was differ from previously reported by Manila-fajardo and Cervancia (2020) for Coffea liberica var. liberica where the mean of calorie content based on nectar sucrose content is ranged from 0.87 to $2.98 \mathrm{cal} / \mu \mathrm{L}$. Furthermore, Bareke et al. (2021) reported that the sugar content from Coffea arabica L. nectar is ranged from 2.8 to $4.6 \mathrm{mg} /$ flower/day.

\section{Production of coffee}

The results showed that the production of coffee before pollination by the stingless bee Tetragonula $\mathrm{sp}$. was $1,230.8 \mathrm{~kg} / \mathrm{ha}$, but after pollination by Tetragonula $\mathrm{sp}$. was $49.1 \%$ became $3,605.7 \mathrm{~kg} / \mathrm{ha}$ from previous production. In addition, the fruit production before pollination by Tetragonula sp. was 2,127.2 fruit/tree, but after pollination by Tetragonula sp. was $59.2 \%$ became $8,309.2$ fruit/tree from previous production (Table 5). It indicates that the involvement of stingless bee Tetragonula sp. as an agent of pollinators can improve the productivity of coffee, especially coffee production per hectare and fruit production per tree, however other parameters have not been studied such as fruit weight, fruit production per bunches, and the involvement of other insects as the pollinator. Veddeler et al. (2008) reported that the bee visiting the coffee flowers (Coffea arabica) increased coffee yield until $80 \%$ and $800 \%$ in net revenues. Furthermore, Calderone (2012) reported that the honey bees increased production $28.9 \%$ from plants total as an indirectly dependent on the pollinators. These results showed that the diversity of bee species is more effective and productive to enhances the productivity of perennial crops by pollination services (Rogers et al. 2014).

Table 4. Nectar sucrose content from coffee flowers in various time and day of observe

\begin{tabular}{lccc}
\hline \multirow{2}{*}{ Observe days } & \multicolumn{3}{c}{ Time collection } \\
\cline { 2 - 4 } & $\begin{array}{c}\text { Morning } \\
(\boldsymbol{\%})\end{array}$ & $\begin{array}{c}\text { Afternoon } \\
(\boldsymbol{\%})\end{array}$ & $\begin{array}{c}\text { Evening } \\
(\boldsymbol{\%})\end{array}$ \\
\hline First $(\%)$ & $23.3 \pm 0.03^{\mathrm{ay}}$ & $23.3 \pm 0.00^{\mathrm{az}}$ & $23.2 \pm 0.00^{\mathrm{bz}}$ \\
Second (\%) & $24.4 \pm 0.00^{\mathrm{bx}}$ & $24.4 \pm 0.03^{\mathrm{by}}$ & $27.1 \pm 0.03^{\mathrm{ay}}$ \\
Third (\%) & $20.6 \pm 0.03^{\mathrm{cz}}$ & $35.0 \pm 0.00^{\mathrm{ax}}$ & $29.0 \pm 0.03^{\mathrm{bx}}$ \\
\hline Note: $\mathrm{a}, \mathrm{b}, \mathrm{c}$ Different superscripts within rows indicate differences \\
at $\mathrm{P}<0.01 ;$ x,y,z Different superscripts within columns indicate \\
differences at $\mathrm{P}<0.01 ;$ Data was presented in mean \pm standard error
\end{tabular}


Table 5. Estimation of coffee production before and after pollinated by stingless bee Tetragonula sp. during May to October period

\begin{tabular}{lccccc}
\hline Parameters & $\begin{array}{c}\text { Before pollinated } \\
\text { by bees }\end{array}$ & $\begin{array}{c}\text { After pollinated } \\
\text { by bees }\end{array}$ & Total & $\begin{array}{c}\text { Amount } \\
\text { increasing (kg) }\end{array}$ & $\begin{array}{c}\text { Percentage } \\
\text { increasing }(\%)\end{array}$ \\
\hline Coffee production (kg/ha) & $1,230.8$ & $3,605.7$ & $4,836.5$ & $2,374.9$ & 49.1 \\
Fruit production (fruit/tree) & $2,127.2$ & $8,309.2$ & $10,436.4$ & $6,182.0$ & 59.2 \\
\hline
\end{tabular}

Table 6. Production of honey from honeybee Apis cerana and stingless bee Tetragonula sp.

\begin{tabular}{ll}
\hline Parameters & Weight \\
\hline $\begin{array}{l}\text { Production of honey from } \\
\text { Tetragonula } \text { sp. (g/hive/5 months) }\end{array}$ & $5.74 \pm 0.62$ \\
$\begin{array}{l}\text { Production of honey from } \\
\text { Apis cerana (g/hive/5 months) }\end{array}$ & $301.35 \pm 13.10$ \\
\hline
\end{tabular}

This study in line with reported by Bezabih and Gebretsadikan (2014) that the onion $50 \%$ is pollinated by honeybee Apis mellifera $\mathrm{L}$. and increased onion production was $41.2 \%$, seeds 1,000 mass was $25 \%$, and percentage of germination was 68\%. Furthermore, Azmi et al. (2016) reported that the chili pollinated by stingless bee Heterotrigona itama and hand cross pollination resulted in longer, heavier, and greater seed number per fruit than chilies self-pollinated. Furthermore, Putra et al. (2014) reported that the tomato flowers pollinated by honey bee Apis cerana more efficiently $(80.3 \%)$ than pollinated by stingless bee Trigona iridipennis $(70.2 \%)$, however weight and size of tomato fruit is similar. Kishan Tej et al. (2017) reported that the stingless bee Tetragonula iridipennis Smith used as the pollinator in greenhouse can be increased the production attributes of cucumber (fruit length, girth, weight, fruit number per plant, and production per plant) than control (without stingless bee as the pollinator). Furthermore, Layek et al. (2021) reported that the open pollination of stingless bee and honeybee can increase watermelon fruit set is $14 \%$ for Tetragonula iridipennis and $17 \%$ for Apis mellifera compared to open pollination and geitonogamy. In addition, open pollination added by stingless bee and honeybee increased the quality of watermelon (length, girth, and weight of fruits) then open pollination and geitonogamy, however is lower compared to cross pollination using hand.

\section{Production of honey}

The results showed that the honey production from stingless bee Tetragonula sp. after 5 months meliponiculture in the coffee plantation was $5.74 \mathrm{~g} / / \mathrm{hive}$ (Table 6). Its honey production is described by the stingless bee Tetragonula sp. might be the colonies have started to develop and focused on constructing their nest. Supeno and Erwan (2013) reported that the stingless bee Tetragonula $\mathrm{sp}$. can produce honey $300 \mathrm{~mL} / \mathrm{hive}$ for 8 months meliponiculture in North Lombok, Indonesia. Honey production in our study was different from that reported by Agussalim et al. (2020) for Tetragonula laeviceps after meliponiculture for 4 months ranged from 60 to 263 $\mathrm{ml} /$ hive (79.2 to $328 \mathrm{~g} /$ hive). In addition, Erwan et al.
(2020) reported that the volume of honey pots from Tetragonula sp. is ranged from 0.14 to $0.37 \mathrm{~mL} / \mathrm{pot}$, total production for 1 month meliponiculture in North Lombok is $9.18 \mathrm{~mL} /$ bamboo hive and $18.72 \mathrm{~mL} /$ box hive.

Production of honey from Apis cerana after beekeeping for 5 months was $301.35 \mathrm{~g} /$ hive (Table 6) with coffee flowers as the nectar source. This production was differ from previously studied by Schouten et al. (2019) reported that the annual honey production from Apis cerana javana Fabr. that beekeeping in Java, Bali, Nusa Penida, and Sumbawa is ranged from 0.5 to $5 \mathrm{~kg} /$ hive. The difference in honey production for each species Tetragonula sp. and Apis cerana is affected by the difference of plant types as the nectar source, activity of foragers to collect nectar, bee species or genetics, and climate condition (temperature and humidity). It can be concluded that the role of stingless bee Tetragonula sp. as an agent of pollinators can increased the production of coffee (Coffea robusta) is $49.1 \%$ and coffee fruit increased 59.2\%. Production of nectar from coffee flowers is $78.45 \mathrm{~g} /$ tree/4 months $(103,739.44 \mathrm{~g} / \mathrm{ha})$ and production of pollen is $13.92 \mathrm{~g} /$ tree/4 months $(18,405.86$ $\mathrm{g} / \mathrm{ha}$ ). Production of honey from stingless bee Tetragonula sp. is $5.74 \mathrm{~mL} /$ hive/5 months and Apis cerana is 301.35 $\mathrm{mL} / \mathrm{hive} / 5$ months.

\section{ACKNOWLEDGEMENTS}

The authors would like to thank the Directorate of Research and Community Service, Ministry of Education, Culture, Research, and Technology of the Republic of Indonesia for financial support of this research and also to all coffee Farmers in Lantan (Central Lombok, West Nusa Tenggara, Indonesia) for permitting our team to performed the study.

\section{REFERENCES}

Abrol DP. 2011. Foraging, in: Hepburn H, Radlof S. (eds). Honeybees of Asia. Springer, Berlin, Heidelberg. DOI: 10.1007/978-3-642-164224_12

Agus A, Agussalim, Nurliyani, Umami N, Budisatria IGS. 2019. Evaluation of antioxidant activity, phenolic, flavonoid and vitamin $\mathrm{C}$ content of several honeys produced by the Indonesian stingless bee: Tetragonula laeviceps. Livest Res Rural Dev 31: 152.

Agussalim A, Agus A, Umami N, Budisatria IGS. 2018. The type of honeybees forages in Sub-district of Pakem Sleman and Nglipar Gunungkidul Yogyakarta. Bul Peternak 42: 50-56. DOI: 10.21059/buletinpeternak.v42i1.28294

Agussalim, Agus A, Nurliyani, Umami N. 2019. The sugar content profile of honey produced by the Indonesian Stingless bee, Tetragonula laeviceps, from different regions. Livest Res Rural Dev 31: 91. 
Agussalim, Nurliyani, Umami N, Agus A. 2020. The honey and propolis production from Indonesian stingless bee: Tetragonula laeviceps Livest Res Rural Dev 32: 121.

Agussalim, Umami N, Nurliyani, Agus A. 2021. The physicochemical composition of honey from Indonesian stingless bee (Tetragonula laeviceps). Biodiversitas 22: 3257-3263. DOI: 10.13057/biodiv/d220820

AOAC. 2005. Official Method of Association of Official Analytical Chemist. 18th Edition. Association of Official Analytical Chemist. Benjamin Franklin Station, Washington D.C.

Atmowidi T, Riyanti P, Sutrisna A. 2008. Pollination effectiveness of Apis Cerana Fabricus and Apis Mellifera Linnaeus (Hymenoptera: Apidae) in Jatropha Curcas L. (Euphorbiaceae). Biotropia 15: 129-134. DOI: 10.11598/btb.2008.15.2.72

Azmi WA, Seng CT, Solihin NS. 2016. Pollination efficiency of the stingless bee, Heterotrigona itama (Hymenoptera: Apidae) on chili (Capsicum annuum) in greenhouse. J Trop Plant Physiol 8: 1-11.

Bareke T, Addi A, Wakjira K, Kumsa T. 2021. Dynamics of nectar secretion, honey production potential and colony carrying capacity of Coffea arabica L. (Rubiaceae). J Agric Environ Int Dev 115: 125 138. DOI: $10.12895 /$ jaeid.20211.1556.

Bezabih G, Gebretsadikan K. 2014. Managed honeybees (Apis mellifera L.) increase onion (Alliun cepa) seed yield and quality. Livest Res Rural Dev 26: 8-20.

BPS-Statistics Indonesia, 2019. Indonesian Coffee Statistics 2019. BPSStatistics Indonesia, Jakarta. [Indonesian]

BPS-Statistics Indonesia, 2018. Indonsian Coffee Statistics 2018. BPSStatistics Indonesia, Jakarta. [Indonesian]

BPS-Statistics Indonesia, 2017. Indonesian Coffee Statistics 2017. BPSStatistics Indonesia, Jakarta. [Indonesian]

Calderone NW. 2012. Insect pollinated crops, insect pollinators and US agriculture: Trend analysis of aggregate data for the period 1992 2009. PLoS One 7: e37235. DOI: 10.1371/journal.pone.0037235

Erwan, Astuti M, Syamsuhaidi, Muhsinin M, Agussalim. 2020. The effect of different beehives on the activity of foragers, honey pots number and honey production from stingless bee Tetragonula sp. Livest Res Rural Dev 32: 158.

Erwan, Suhardin, Syamsuhaidi, Purnamasari DK, Muhsinin M, Agussalim. 2021. Propolis mixture production and foragers daily activity of stingless bee Tetragonula sp. in bamboo and box hives Livest Res Rural Dev 33: 82.

Kishan Tej M, Srinivasan MR, Rajashree V, Thakur RK. 2017. Stingless bee Tetragonula iridipennis Smith for pollination of greenhouse cucumber. J Entomol Zool Stud 5: 1729-1733.

Klein AM, Steffan-Dewenter I, Tscharntke T. 2003. Fruit set of highland coffee increases with the diversity of pollinating bees. Proc R Soc B Biol Sci 270: 955-961. DOI: 10.1098/rspb.2002.2306
Layek U, Kundu A, Bisui S, Karmakar P. 2021. Impact of managed stingless bee and western honey bee colonies on native pollinators and yield of watermelon: A comparative study. Ann Agric Sci 66: 3845. DOI: 10.1016/j.aoas.2021.02.004

Manila-fajardo AC, Cervancia CR. 2020. Nectar biology and its influence on the pollination of Coffea liberica W. Bull ex Hiern var. liberica. Philipp Coffee J 1: 14-22.

Putra RE, Permana AD, Kinasih I. 2014. Application of Asiatic honey bees (Apis cerana) and stingless bees (Trigona laeviceps) as pollinator agents of hot pepper (Capsicum annuum L.) at local Indonesia farm system. Psyche (Stuttg) 687979: 1-5. DOI: $10.1155 / 2014 / 687979$

Putra RE, Kinasih I. 2014. Efficiency of local Indonesia honey bees (Apis cerana L.) and stingless bee (Trigona iridipennis) on tomato (Lycopersicon esculentum Mill.) pollination. Pakistan J Biol Sci 17: 86-91. DOI: $10.3923 /$ pjbs.2014.86.91

Quezada-Euan JJG. 2018. Stingless bees of Mexico: The Biology, Management and Conservation of an Ancient Heritage. Springer, Switzerland. DOI: 10.1007/978-3-319-77785-6_7

Rogers SR, Tarpy DR, Burrack HJ. 2014. Bee species diversity enhances productivity and stability in a perennial crop. PLoS One 9: e97307. DOI: 10.1371 /journal.pone.0097307

Roubik DW. 2002. The value of bees to the coffee harvest. Nature 417: 708. DOI: 10.1080/00313029400169831

Schouten C, Lloyd D, Lloyd H. 2019. Beekeeping with the asian honey bee (Apis cerana javana Fabr.) in the Indonesian Islands of Java, Bali, Nusa Penida, and Sumbawa. Bee World 96: 45-49. DOI: 10.1080/0005772x.2018.1564497

Steel RGD, Torrie JH, Zoberer DA. 1997. Principles and Procedures of Statistics a Biometrical Approach. 3rd Edition. McGraw-Hill Inc., New York.

Supeno B, Erwan. 2013. Pemanfaatan teknologi pakan lebah tanpa bunga tanaman untuk menjadikan pulau Lombok sebagai daerah sentra produksi nasional, in: Seminar Nasional Insentif Riset SINas Membangun Sinergi Riset Nasional Untuk Kemandirian Teknologi. Asdep Relevansi Program Riptek, Deputi Bidang Relevansi dan Produktivitas Iptek, Kementerian Riset dan Teknologi, Indonesia, Jakarta. [Indonesian]

Veddeler D, Olschewski R, Tscharntke T, Klein AM. 2008. The contribution of non-managed social bees to coffee production: New economic insights based on farm-scale yield data. Agrofor Syst 73: 109-114. DOI: $10.1007 / \mathrm{s} 10457-008-9120-\mathrm{y}$

Vergara $\mathrm{CH}$, Badano EI. 2009. Pollinator diversity increases fruit production in Mexican coffee plantations: The importance of rustic management systems. Agric Ecosyst Environ 129: 117-123. DOI: 10.1016/j.agee.2008.08.001 